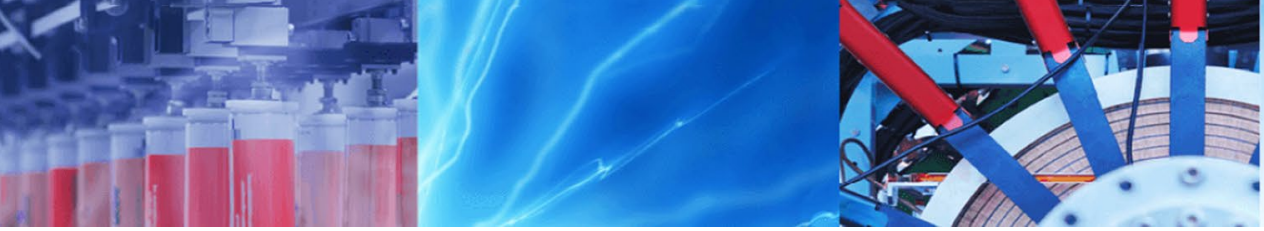

Research Article

\title{
Assembly of quinone-based renewable biobattery using redox molecules from Lawsonia inermis
}

\author{
Halima $\mathrm{Ali}^{1} \cdot$ Immaculata O. Onuigbo ${ }^{1} \cdot$ Tosin E. Fabunmi $^{1} \cdot$ Muhammed Yahaya ${ }^{1} \cdot$ Madu Joshua ${ }^{1} \cdot$ Bolade Agboola $^{1}$. \\ Wan Jin Jahng ${ }^{1}$ (D)
}

(c) Springer Nature Switzerland AG 2019

\begin{abstract}
The current study tested the hypothesis whether common plant extracts could be used as redox molecules in biobattery. Natural quinone molecules were extracted from Lawsonia inermis (henna) via sequential extraction using hexane, ethyl acetate, methanol and $80 \%$ methanol in water, followed by purification using column chromatography to examine their potential function as redox molecules in biobattery. A combination of UV-visible spectroscopy and gas chromatography-mass spectrometry (GC-MS) analysis confirmed the presence of quinones in the extracted fractions. UV analysis showed maximum absorbance at $295 \mathrm{~nm}$ and $450 \mathrm{~nm}$ which correspond to 4-t-butyl-1,2-benzoquinone and duroquinone. In addition, GC-MS analysis of the henna extract confirmed the presence of tocopherol (vitamin E) as a potential redox molecule. We determined the impact of the type of electrolyte, electrode, salt bridge and volume of extract on the overall efficiency of biobattery. Among the different cell combinations tested, the optimum battery with a maximum voltage of $0.97 \mathrm{~V}$ was achieved using a carbon \|quinone cathodic half-cell, copper\|sulphuric acid anodic half-cell and a KCl (1.0 M) salt bridge. Our experiments demonstrate that natural redox molecules from common African plants, including $L$. inermis extracts, can serve as source of electrical energy and alternative materials for the renewable battery.
\end{abstract}

Keywords Biobattery $\cdot$ Quinone $\cdot$ Natural redox molecules $\cdot$ Electrode $\cdot$ Electrical energy storage $\cdot$ Electrolyte

\section{Introduction}

The current electricity supply in the world has evolved from the conventional fossil fuel-based electricity generation to one that involves integrating new renewable energy technologies. The new renewable resources have been majorly dominated by solar and wind energy [1]. A key application of renewable electrical energy is in electric vehicles which support the low carbon emission agenda of the Paris 2015 Agreement on global $\mathrm{CO}_{2}$ emissions [2]. However, a major drawback to the full transition to $100 \%$ renewable energy usage is the economics of the storage systems. For example, Günther and Eichinger examined the economic implications of having a 100\% renewable electricity supply in Java-Bali, considering the initial capital expenditure, the operation and maintenance costs alongside the costs of the continuous renovation of the system's components. Their study concluded that a generation system based solely on renewable resources could potentially face many challenges due to the high dependence on costly storage capacities [3].

Furthermore, the inherent challenge of the variability of sustainable energy sources [4], including sun and wind, makes it difficult to transition from fossil energy such as natural gas and coal technologies which are more flexible to deploy [5]. Energy storage has been identified as the solution to the issue of variability of supply as it helps store the energy during the peak production hours in order to make electricity available when needed. Better energy storage capacities also make it

$\triangle$ Wan Jin Jahng, wan.jahng@aun.edu.ng|'Organic Chemistry Research Laboratory, Department of Petroleum Chemistry, American University of Nigeria, Yola, Nigeria.

SN Applied Sciences (2019) 1:597 | https://doi.org/10.1007/s42452-019-0577-2

Received: 5 March 2019 / Accepted: 8 May 2019 / Published online: 18 May 2019 
possible to decentralize energy supply systems via microgrids $[6,7]$. Microgrids involve setting up of mini integrated electricity generation, storage and distribution units [8].

Energy storage involving batteries is one of the most important and efficient ways of storing electrical energy. The electrochemical energy storage device offers the best combination of efficiency, cost and flexibility and has become essential to our modern life $[9,10]$. A battery stores electricity from redox chemical reaction and is composed of a positive cathode electrode, a negative anode electrode, and an electrolyte system that aids the continuous flow of electrons. Majority of the common batteries are made from inorganic metal materials, including copper, zinc, lithium, tin, nickel and mercury. However, most of these metals are costly [11], toxic, non-biodegradable and have negative impact on the environment [12]. Therefore, much research has been directed towards the development of new materials from renewable sources that mitigates these glaring downsides.

Several biomaterials have been explored as viable alternatives for cathodes, anodes and electrolytes in batteries. For a biomaterial to serve as an efficient anode in energy storage devices, it must be biodegradable and exhibit good physicochemical properties that would support high charge storage densities with minimal economic implications [13]. Biobattery has inherent advantages, including high efficiency at room temperatures and near neutral $\mathrm{pH}$, low cost of fabrication, ease of miniaturization and environmental friendliness over the chemical-based energy systems. These devices utilize biological systems, including enzymes [14], proteins, bacteria [15], to induce oxidation and reduction reactions at the anode and cathode, respectively. Organic redox batteries have a longer life span of about 15 years and up to 5000 recharge cycles compared to lithium-ion and lead acid batteries that degrade after 1000 cycles [16].

Quinones are natural dyes in plants [17] and are the central structural units for electron transfer and energy storage during photosynthesis. These unique features of quinone and its derivatives are being explored in the construction of bio-inspired energy harvesting and conversion systems [18, 19]. A quinone molecule contains two carbonyl groups within a six membered ring [20], including benzene, naphthalene and anthracene backbones that undergo rapid reversible redox reactions [21, 22]. Quinones show the electron transfer property needed in an electrolyte [23, 24], and an example is hydroxy-1,4-naphthoquinones [25]. They exhibit different electrochemical behaviours in various media [21], getting reduced to semiquinones or hydroquinones by gaining two electrons and two protons, and getting oxidized by losing two protons and two electrons [26].
We hypothesized that common plant extracts could harness the energy trapping capacity of natural quinones towards the storage of charges in galvanic cells. Our rationale of energy storage capacity comes from the ability to undergo resonance-stabilized, electron transfer and rapid reversible redox reactions of quinone-like molecules. The current study focused on replacing the metal-based batteries with non-toxic, organic-based, biodegradable redox materials, including tocopherol. We explored the potential application of natural quinone mixtures extracted directly from henna plants vis-à-vis a graphite electrode in making biodegradable batteries. Several variables, including extraction media, duration of extraction, cell chamber width, electrode-electrolyte combinations and the potential application of quinones as charge transfer coatings in solid-state batteries, were investigated to elucidate their effects on the efficiency of bio-based batteries.

\section{Materials and methods}

Fresh leaves of Lawsonia inermis (henna) were obtained from a local market in Yola, Nigeria. All chemicals used were analytical grade and obtained from Sigma-Aldrich.

\subsection{Extraction of the natural dyes}

Lawsonia inermis leaves were thoroughly washed and airdried for two weeks at room temperature $\left(27 \pm 2^{\circ} \mathrm{C}\right)$ and then pulverized to fine powder using waring blender. The plant powder $(60 \mathrm{~g})$ was placed in a beaker and extracted sequentially using $\mathrm{n}$-hexane, ethyl acetate, methanol and $80 \%(\mathrm{v} / \mathrm{v})$ methanol in water as solvents. During the extraction, $150 \mathrm{ml}$ of each solvent was used; each solvent mixture was left for $4 \mathrm{~h}$ before filtration. All the extracts were stored with air-tight glass containers in a refrigerator at $4{ }^{\circ} \mathrm{C}$.

\subsection{Analysis of quinone}

Thin layer chromatography (TLC) was employed to identify the presence of quinones in the sample extracts. A mixture of hexane and acetone (20:80) with $1 \%$ acetic acid was used as eluent. The physical appearance of the spots from the extract was observed, and the Rf values were calculated and compared to standard $\mathrm{Rf}$ of values of quinone from the literature. The Rf values of the henna-ethyl acetate extract and henna-methanol $80 \%(\mathrm{v} / \mathrm{v})$ extracts were corroborated by available literature. 


\subsection{Column chromatographic isolation of quinones}

Quinones were isolated from the henna plant extracts using column chromatography. The column $(1.0 \times 76 \mathrm{~cm})$ was packed using aluminium oxide (50-200 microns) by wet packing method. About $10 \mathrm{ml}$ of the henna-methanol $80 \%(\mathrm{v} / \mathrm{v})$ extract was loaded onto the column, and the column was eluted with a mixture of chloroform and methanol (19:1) until all the separate components of the extract had been collected. The same method was used to isolate quinones from the henna-ethyl acetate extract.

\subsection{UV-Vis spectroscopy and mass spectrometry analysis of extracts}

The ethyl acetate, $n$-hexane, $80 \%$ methanol/distilled water extract were filtered using Puradisc $0.2 \mu \mathrm{m}$ PES filter (Whatman, GE Healthcare) to obtain a sample for the UV-visible spectrometric analysis. The absorbance of each extract in the UV-visible region (200-800 $\mathrm{nm}$ ) was measured using a 6850 Jenway UV-Vis spectrophotometer.

The fractionated samples allowed to evaporate to dryness were reconstituted using hexane. The compounds in the fractions of the henna leaf extracts were analyzed qualitatively using an Agilent $7890 \mathrm{~A}$ gas chromatography (GC) system having a HP-5 column (30 $\mathrm{m} \times 250 \mu \mathrm{m}$ ID, $0.25 \mu \mathrm{m}$ film thickness) coupled to an Agilent 5975C inert mass spectrometer detector. Analysis was carried out with Helium (99.995\% purity) as the carrier gas at a rate of $1.5 \mathrm{~mL} / \mathrm{min}$. The temperature of the oven was initially set at $60{ }^{\circ} \mathrm{C}$ to $250^{\circ} \mathrm{C}$ as gradient increase at a rate of $20^{\circ} \mathrm{C} /$ min and set to hold for $1 \mathrm{~min}$, while the final temperature was set at $300^{\circ} \mathrm{C}\left(10^{\circ} \mathrm{C} / \mathrm{min}\right)$ and held for $4 \mathrm{~min}$. The positive ion electron impact (EI) mass spectra were recorded at ionization energy of $70 \mathrm{eV}$, and the injector volume was $1 \mu \mathrm{L}$ with Splitless mode. The organic compounds were determined by comparing the mass spectra of the peaks with the mass spectra of the molecules from NIST database (NIST MS search 2011 version).

\subsection{Biobattery assembly}

The isolated quinones as well as the whole extracts were examined in the biobatteries. The quinone extracts were explored in both liquid-based and solid-based batteries. The liquid-based battery consisted of two chambers: (a) the cathodic half-cell containing a carbon electrode immersed in the henna-ethyl acetate extract $(30 \mathrm{ml})$ and (b) the anodic half-cell which consisted of copper rod electrode immersed in dilute sulphuric acid $(30 \mathrm{ml})$. Solutions of $\mathrm{NaCl}(1.0 \mathrm{M})$ and $\mathrm{KCl}(1.0 \mathrm{M})$ were alternated as salt bridge materials. Both ends of the bridge were closed with cotton wool, and the salt bridge was immersed such that each end was in each chamber. The circuit was completed by connecting the cathodic and anodic rods with alligator wires to a multimeter which was set to read in millivolts under direct current (DC). The entire process was repeated using the henna-methanol $80 \%(\mathrm{v} / \mathrm{v})$ extract.

Next, a solid-based battery using natural redox material was assembled. An aluminium foil was soaked in the henna-ethyl acetate extract, while another piece of aluminium foil was coated with graphite. $\mathrm{An} \mathrm{I}^{-} / /_{3}{ }^{-}$electrolyte system was prepared and dropped on top of the graphite-aluminium electrode. The two electrodes were then connected with alligator clips to the multimeter and then placed one on top of the other. On the completion of the set-up, the cell did not produce stable voltage readings until after $10 \mathrm{~min}$. A control circuit which was assembled using the same anode and electrolyte system save for being coated with the quinone extracts was also set up. The entire process was repeated using the hennamethanol $80 \%(\mathrm{v} / \mathrm{v})$ extract.

The anodic and cathodic half reactions of the cell are shown as follows in Eqs. (1) to (4);

Anodic half reaction (oxidation)

$\mathrm{Cu}(\mathrm{s})+\rightarrow \mathrm{Cu}^{2+}+2 \mathrm{e}$

At the anode, the copper metal is oxidized, releasing two electrons externally to the multimeter and then to the cathode.

Cathodic half reaction (reduction)

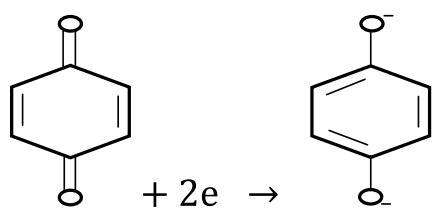

Overall reaction;<smiles>O=C1C=CC(=O)C=C1</smiles>

Thus, the cell is represented as the following equation;

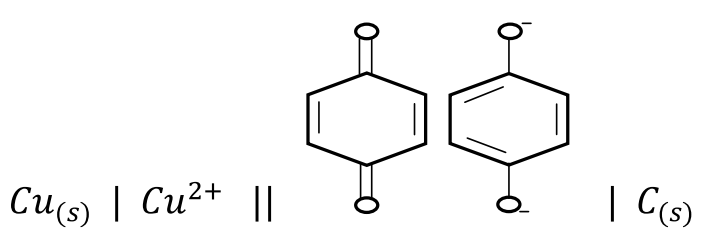

From the above cell representation, the copper metal electrode is oxidized to form the cation. The electrons 
lost by the copper (oxidation) are sent externally where they are received by the quinone molecule to form the anion. The salt bridge maintains electrical neutrality at the two half-cells.

\subsection{Evaluation of the Cell Components}

We examined various cell parameters, including extract volume, electrode contacting surface area, anode type and salt bridge components to determine their effects on the efficiency of the biobatteries. We investigated the volume of the extracts to determine how varying the volumes affects the potential difference of the cell. Henna-ethyl acetate extracts $(20,30,100$ and $150 \mathrm{ml})$, at different times, were measured into one chamber, while dilute sulphuric acid of the same respective volumes was added into the second chamber. The voltage was recorded for each set of volume.

Furthermore, we investigated the effect of increasing the contacting surface areas of the electrode on the cell voltage. We kept the quantity of the electrolyte constant while varying the length and diameter of the electrodes.

In addition, we varied the anode electrolyte as well as the salt bridge solution to see how it affects the opencircuit voltage values. A copper sulphate solution and potassium chloride $(1.0 \mathrm{M})$ were prepared to replace the sulphuric acid and the sodium chloride (1.0 M) that were previously used. The voltage was recorded accordingly.

\section{Results and discussion}

The $\mathrm{Rf}$ values of all the extracts were compared to the standard quinone $\mathrm{Rf}$ values from the literature. The hennaethyl acetate and henna-methanol $80 \%(\mathrm{v} / \mathrm{v})$ had Rf values of 0.44 corresponding to the $\mathrm{Rf}$ value of 5-hydroxy-2-methyl-1,4-naphthoquinone indicating the possible presence of the quinones in these fractions.

All the extracts were analysed using UV-VIS spectroscopy at wavelength range of $200 \mathrm{~nm}$ to $800 \mathrm{~nm}$. The absorption spectra indicated that lambda max absorption peaks were within the ranges of $293 \mathrm{~nm}-295 \mathrm{~nm}$, $310 \mathrm{~nm}-350 \mathrm{~nm}$ and $400 \mathrm{~nm}-485 \mathrm{~nm}$. The peaks under the range $293 \mathrm{~nm}-295 \mathrm{~nm}$ corresponded with 4-t-butyl1,2-benzoquinone [27]. Various other peaks around $420 \mathrm{~nm}, 370 \mathrm{~nm}$ and $390 \mathrm{~nm}$ suggested the presence of duroquinone [28], 2-hydroxy-1,4-naphthoquinone [29] and 1,4-naphthoquinone [25], respectively. The hennaethyl acetate extract absorption spectrum was observed to have maximum wavelengths at $295 \mathrm{~nm}$ and $410 \mathrm{~nm}$.

All extracts were further analysed using GC-MS spectrometry. The fraction of henna extracts in hexane identified the presence of tocopherol (vitamin E) (Fig. 1).
Fig. 1 GC-MS analysis of plant fractions. a $m / z$ analysis of the unknown molecule at 16 min retention time shows $m / z=165$ as the base peak and $m / z=430$ as the molecular ion peak. b NIST database search represents tocopherol (vitamin E) and fragmentation pattern confirmed the identity of tocopherol



$\mathrm{m} / \mathrm{z}$

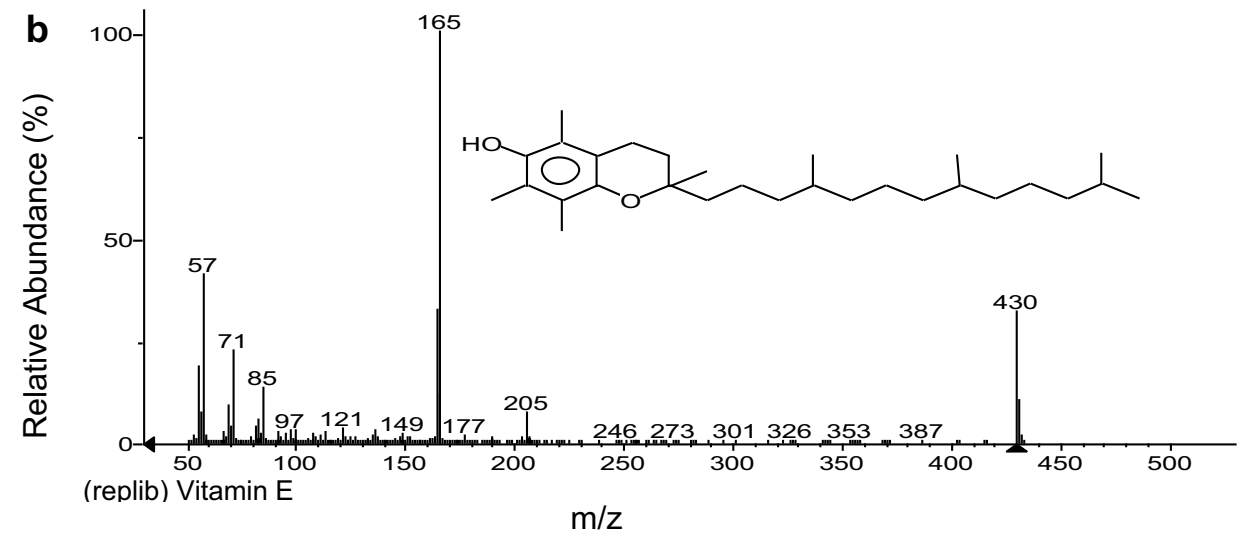


Tocopherol is a natural redox molecule with a high antioxidant efficiency in plants [30]. Their capability to undergo a quasi-reversible two one-electron reduction process makes them applicable in electrochemical cells.

The cathodic half-cell consisted of a combination of carbon immersed in henna-ethyl acetate extract containing redox molecules including duroquinone and tocopherol, while the anodic half-cell consists of copper immersed in dilute sulphuric acid (Fig. 2). The salt bridge was used to connect the two half-cells which gave rise to a voltage of $350 \mathrm{mV}$ (Fig. 3). Since carbon is an inert electrode, it can be inferred that the transfer of electrons is mainly between copper and the quinone. The carbon electrode only facilitates the transfer due to its large surface area, high electronic conductivity and excellent chemical stability.

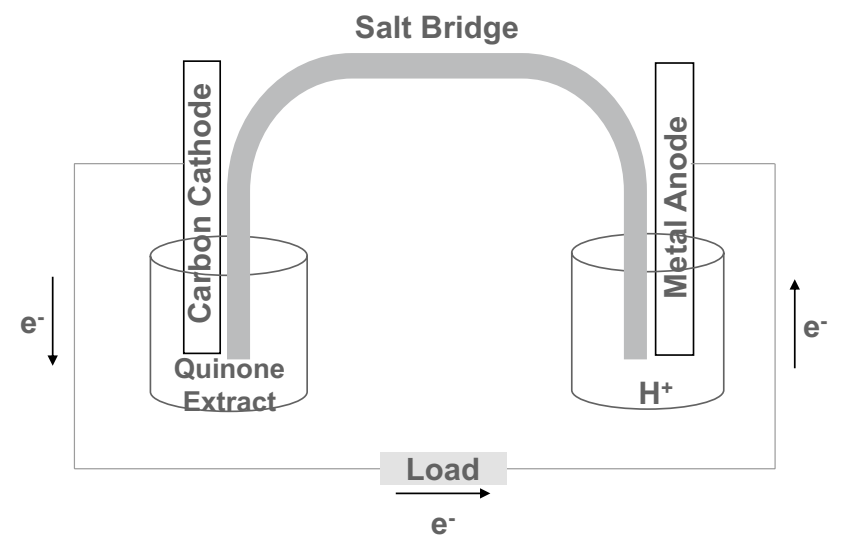

Fig. 2 The assembly of the liquid quinone extract based biobattery. The scheme shows that oxidation-reduction reactions of quinones take place at each electrode with an acid $(\mathrm{pH} 0)$ solution which supplies the protons $\left(\mathrm{H}^{+}\right)$
Table 1 shows how varying the volume of the extracts affects the electrochemical performance. Our results show that a $50 \%$ increase in the volumes of the electrolyte from 20 to $30 \mathrm{ml}$ generated a $3 \%$ increase in the output voltage and a $233 \%$ increase in volume from 30 to $100 \mathrm{ml}$ corresponded to $8 \%$ increase in the output voltage. Thus, we infer that increasing the volume of the electrolyte raises the open-circuit voltage minimally [31].

We hypothesized that increasing the surface area of contact by using either a longer rod or one with a larger diameter, the voltage would increase due to more surface available for electron transfer to take place. We found that the voltage increased $29 \%$ from 350 to $451 \mathrm{mV}$ with larger contact surface area. Similar findings suggested that the use of nanostructured materials with larger contact surface area, including single-walled carbon nanotubes, metal nanoparticles and graphene to coat the electrode surface increases output voltage [32].

The anode is the negative terminal of an electrochemical cell where the oxidation reaction takes place. It is responsible for the regeneration of electrons and its nature greatly influences the overall performance of an electrochemical cell. We observed a change in the open-circuit voltage by

Table 1 Change in cell potential with a variation in electrolyte volume

\begin{tabular}{lll}
\hline $\begin{array}{l}\text { Volume of extract } \\
(\mathrm{mL})\end{array}$ & $\begin{array}{l}\text { Volume of dilute sulphuric } \\
\text { acid }(\mathrm{mL})\end{array}$ & $\begin{array}{l}\text { Mean open- } \\
\text { circuit voltage } \\
(\mathrm{mV})\end{array}$ \\
\hline 20 & 20 & 339 \\
30 & 30 & 349 \\
100 & 100 & 377 \\
150 & 150 & 394 \\
\hline
\end{tabular}

Fig. 3 Representative assembly of biobattery using plant extracts. The cathodic half-cell includes carbon electrode in henna-ethyl acetate containing redox molecules including tocopherol, while the anodic half-cell is a copper electrode in dilute sulphuric acid. The two half-cells connected using the salt bridge containing potassium chloride give $350 \mathrm{mV}$ as shown

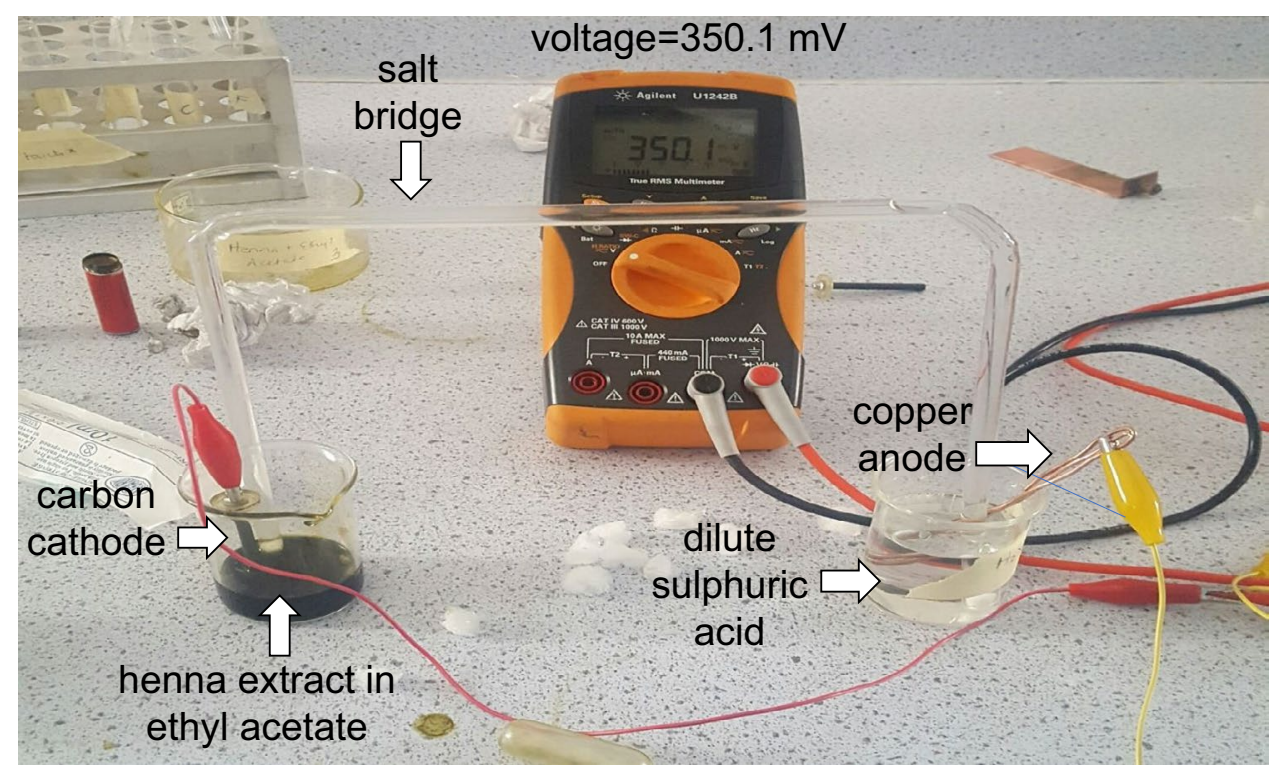

SN Applied Sciences A SPRINGER NATURE journal 
Table 2 Effects on the cell performance using the different combinations of electrodes and salt bridge materials

\begin{tabular}{llll}
\hline Cathodic half-cell & Anodic half-cell & Salt bridge & $\begin{array}{l}\text { Mean } \\
\text { voltage } \\
(\mathrm{mV})\end{array}$ \\
\hline Carbon||Quinone & Copper||Sulphuric Acid & Sodium chloride & 451 \\
Carbon||Quinone & Copper||Sulphuric Acid & Potassium chloride & 971 \\
Carbon||Quinone & Copper||Copper Sulphate & Sodium chloride & 111 \\
Carbon||Quinone & Copper||Copper Sulphate & Potassium chloride & 169 \\
\hline
\end{tabular}

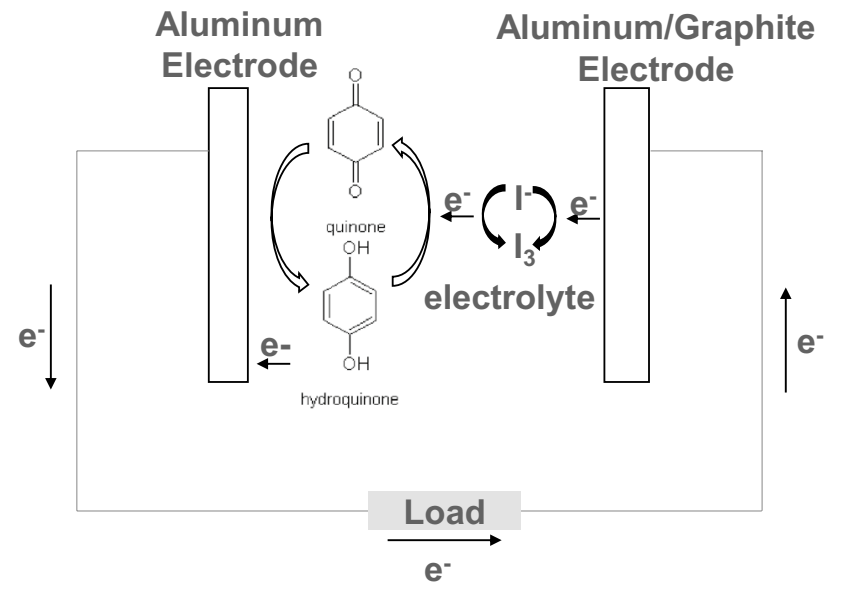

Fig. 4 The assembly of the solid quinone-based biobattery. The scheme shows that solid-state biobattery generates electricity using natural quinone as redox molecules. When the cell was not coated with the quinone extract, the voltage reading was $0.00 \mathrm{mV}$; however, once coated with quinone, we observed an open-circuit voltage reading of $157 \mathrm{mV}$

varying the anode components and the salt bridge molecules as shown in Table 2. Sulphuric acid was found to be a better electrolyte than copper sulphate, while potassium chloride showed better cell performance than sodium chloride as salt bridge materials. The better performance of the $\mathrm{KCl}$ salt bridge can be attributed to $\mathrm{K}^{+}$having a higher transport number than $\mathrm{Na}^{+}$[33] and thus promoting better ion exchange and neutrality than sodium ion.

Next, the efficacy of the quinone was determined as coatings for solid-state batteries and an open-circuit voltage of $157 \mathrm{mV}$ was obtained (Fig. 4). However, the cell potential of the control circuit which was not coated with the quinone extract gave a multimeter reading of $0.00 \mathrm{mV}$. This demonstrates the potential of applying quinones in enhancing redox reactions in solid electrochemical cells.

\section{Conclusions}

Currently, the bulk of our global electricity generation is from carbon-based fossil fuels, including natural gas and coal power plants, even as the renewable energy resources and technologies continue to develop and mature. Our study demonstrates that a simple biobattery can be constructed using easily accessible, cheap, environmentally friendly and sustainable plant extracts containing natural quinone molecules. Quinone materials can be extracted from a variety of plants including, but not limited to, Lawsonia inermis (henna) [34], Hibiscus sabdariffa (zobo/roselle) [35] and Telfairia occidentalis (ugu/fluted pumpkin leaves).

The qualitative analysis of henna extract using GC-MS, UV-Vis spectroscopy after a column chromatographic separation process demonstrated tocopherol as a potential redox molecule in the henna extract. Our experiments to test the efficiency of the biobattery showed that the combination of carbon\|quinone cathodic half-cell, copper||sulphuric acid anodic half-cell and potassium chloride salt bridge material produced the highest electrochemical performance on cell combinations.

Finally, the natural quinone is applicable to the solidstate batteries as its presence initiated electron transfer in the redox reactions, confirming our hypothesis that quinones can serve as electrode and electrolyte materials in biobattery as renewable energy alternatives.

Acknowledgements The current research was supported in part by Research Assistantship and Teaching Assistantship from American University of Nigeria and Julia Foundation. The Research Fund was generously awarded from the Dean's office of Arts and Sciences in American University of Nigeria.

\section{Compliance with ethical standards}

Conflict of interest The authors declare that they have no conflict of interest to disclose.

\section{References}

1. Romli MI, Rajkumar RK, Wan WY, Wai CL, Arelhi R, Isa D (2016) The effectiveness of new solar photovoltaic system with supercapacitor for rural areas. Int J Renew Energy Dev 5(3):249-257. https://doi.org/10.14710/ijred.5.3.249-257

2. Bickert S (2014) Financial measures for electric vehicles: supporting the integration of renewable energy in the mobility sector in Germany. Int J Renew Energy Dev 3(1):45-53. https ://doi.org/10.14710/ijred.3.1.45-53

\section{SN Applied Sciences}


3. Günther M, Eichinger M (2018) Cost optimization for the $100 \%$ renewable electricity scenario for the Java-Bali grid. Int J Renew Energy Dev 7(3):269-276. https://doi.org/10.14710/ ijred.7.3.269-276

4. Jasemi M, Adabi F, Mozafari B, Salahi S (2016) Optimal operation of micro-grids considering the uncertainties of demand and renewable energy resources generation. Int J Renew Energy Dev 5(3):233-248. https://doi.org/10.14710/ijred.5.3.233-248

5. Arndt C, Hartley F, Ireland G, Mahrt K, Merven B, Wright J (2018) Developments in variable renewable energy and implications for developing countries. Curr Sustain Energy Rep 5(4):240-246. https://doi.org/10.1007/s40518-018-0121-9

6. Terzić L, Ramović A, Merzić A, Bosović A, Musić M (2018) Analysis of the implementation of microgrid: case study of widearea Bjelimići. SN Appl Sci 1(1):33. https://doi.org/10.1007/ s42452-018-0036-5

7. Kemausuor F, Sedzro MD, Osei I (2018) Decentralised energy systems in Africa: coordination and integration of off-grid and grid power systems-review of planning tools to identify renewable energy deployment options for rural electrification in Africa. Curr Sustain Energy Rep 5(4):214-223. https://doi. org/10.1007/s40518-018-0118-4

8. Brahmi N, Charfi S, Chaabene M (2017) Optimum sizing algorithm for an off-grid plant considering renewable potentials and load profile. Int J Renew Energy Dev 6(3):213-224. https ://doi.org/10.14710/ijred.6.3.213-224

9. Skyllas-Kazacos M, Chakrabarti MH, Hajimolana SA, Mjalli FS, Saleem M (2011) Progress in flow battery research and development. J Electrochem Soc 158(8):R55-R79. https://doi. org/10.1149/1.3599565

10. May GJ, Davidson A, Monahov B (2018) Lead batteries for utility energy storage: a review. J Energy Storage 15:145-157. https://doi.org/10.1016/j.est.2017.11.008

11. Brinsmead T, Graham P, Hayward J, Ratnam E, Reedman L (2015) Future energy storage trends: An assessment of the economic viability, potential and impacts of electrical energy storage on the NEM Future energy storage trends 2015-2035. https://doi.org/10.4225/08/5852dbcfaffc6

12. Chel A, Kaushik G (2018) Renewable energy technologies for sustainable development of energy efficient building. Alex Eng J 57(2):655-669. https://doi.org/10.1016/j.aej.2017.02.027

13. Kim YJ, Wu W, Chun S-E, Whitacre JF, Bettinger CJ (2013) Biologically derived melanin electrodes in aqueous sodium-ion energy storage devices. Proc Natl Acad Sci 110(52):2091220917. https://doi.org/10.1073/pnas.1314345110

14. Yazdi AA, Preite R, Milton RD, Hickey DP, Minteer SD, Xu J (2017) Rechargeable membraneless glucose biobattery: towards solidstate cathodes for implantable enzymatic devices. J Power Sources 343:103-108. https://doi.org/10.1016/j.jpowsour.2017.01.032

15. Mohammadifar $M$, Choi S (2017) A papertronic, on-demand and disposable biobattery: saliva-activated electricity generation from lyophilized exoelectrogens preinoculated on paper. Adv Mater Technol 2(9):1700127. https://doi.org/10.1002/ admt.201700127

16. Yang B, Hoober-Burkhardt L, Krishnamoorthy S, Murali A, Prakash GKS, Narayanan SR (2016) High-performance aqueous organic flow battery with quinone-based redox couples at both electrodes. J Electrochem Soc 163(7):A1442-A1449. https://doi.org/10.1149/2.1371607jes

17. Huskinson B, Marshak MP, Suh C (2014) A metal-free organicinorganic aqueous flow battery. Nature 505(7482):195-198. https://doi.org/10.1038/nature12909

18. Lee B, Ko Y, Kwon G, Lee S, Ku K, Kim J, Kang K (2018) Exploiting biological systems: toward eco-friendly and high-efficiency rechargeable batteries. Joule 2(1):61-75. https://doi. org/10.1016/j.joule.2017.10.013
19. Son EJ, Kim JH, Kim K, Park CB (2019) Quinone and its derivatives for energy harvesting and storage materials. J Mater Chem A 4(29):11179-11202. https://doi.org/10.1039/C6TA03123D

20. Fabian J, Hartmann H (2013) Light absorption of organic colorants: theoretical treatment and empirical rules. Springer, New York. ISBN 978-3-642-67587-4

21. Guin PS, Das S, Mandal PC (2011) Electrochemical reduction of quinones in different media: a review. Int J Electrochem 2011:22. https://doi.org/10.4061/2011/816202

22. Taran O (2017) Electron transfer between electrically conductive minerals and quinones. Front Chem 5:49. https://doi. org/10.3389/fchem.2017.00049

23. Tong L, Chen Q, Wong AA, Gómez-Bombarelli R (2017) UV-Vis spectrophotometry of quinone flow battery electrolyte for in situ monitoring and improved electrochemical modeling of potential and quinhydrone formation. Phys Chem Chem Phys 19(47):31684-31691. https://doi.org/10.1039/C7CP05881K

24. Petrova SA, Kolodyazhny MV, Ksenzhek OS (1990) Electrochemical properties of some naturally occurring quinones. J Electroanal Chem Interfacial Electrochem 277(1):189-196. https://doi.org/10.1016/0022-0728(90)85101-A

25. Jahanban-Esfahlan A, Davaran S, Moosavi-Movahedi AA, Dastmalchi S (2017) Investigating the interaction of juglone (5-hydroxy-1, 4-naphthoquinone) with serum albumins using spectroscopic and in silico methods. J Iran Chem Soc 14(7):1527-1540. https://doi.org/10.1007/s13738-017-1094-0

26. El-Najjar N, Gali-Muhtasib H, Ketola RA, Vuorela P, Urtti A, Vuorela $H$ (2011) The chemical and biological activities of quinones: overview and implications in analytical detection. Phytochem Rev 10(3):353. https://doi.org/10.1007/s11101-011-9209-1

27. Heitner C, Dimmel D, Schmidt J (2016) Lignin and lignans. CRC Press, Boca Raton, p 686. ISBN 978-1-4200-1580-5

28. Zhu G, Wu G, Sha M, Long D, Yao S (2008) Effects of ionic liquid [bmim][PF6] on absorption spectra and reaction kinetics of the duroquinone triplet state in acetonitrile. J Phys Chem A 112(14):3079-3085. https://doi.org/10.1021/jp077112y

29. Karci F, Ertan N (2005) Visible absorption spectra of some novel heteroarylazo disperse dyes derived from 2-hydroxy1,4-naphthoquinone. Color Technol 121(3):153-157. https:// doi.org/10.1111/j.1478-4408.2005.tb00266.x

30. Munné-Bosch S (2005) The role of a-tocopherol in plant stress tolerance. J Plant Physiol 162(7):743-748. https://doi. org/10.1016/j.jplph.2005.04.022

31. An SJ, Li J, Mohanty D et al (2017) Correlation of electrolyte volume and electrochemical performance in lithiumion pouch cells with graphite anodes and NMC532 cathodes. J Electrochem Soc 164(6):A1195-A1202. https://doi. org/10.1149/2.1131706jes

32. Putzbach W, Ronkainen NJ (2013) Immobilization techniques in the fabrication of nanomaterial-based electrochemical biosensors: a review. Sensors 13(4):4811-4840. https://doi. org/10.3390/s130404811

33. Khare AP (2014) Voltage produced by different salts concentration on single chamber microbial fuel cell. Int J Eng Sci Res Technol 3(3):1448-1452

34. Babula P, Mikelova R, Potesil D, Adam V, Kizek R, Havel L, Sladky Z (2005) Simultaneous determination of 1, 4-naphtoquinone, lawsone, juglone and plumbagin by liquid chromatography with UV detection. Biomed Pap 149:25-28

35. Padmaja H, Sruthi S, Vangalapati M (2014) Review on Hibiscus sabdariffa—a valuable herb. Int J Pharm Life Sci 5(8):3747-3752

Publisher's Note Springer Nature remains neutral with regard to jurisdictional claims in published maps and institutional affiliations. 